\title{
DISTRIBUTION OF TESTATE AMOEBAE IN SALT MARSHES ALONG THE NORTH AMERICAN EAST COAST
}

\author{
W. Roland Gehrels ${ }^{1}$, Dawn Hendon ${ }^{2}$ and Dan J. Charman ${ }^{1}$
}

\begin{abstract}
This study describes the distribution of testate amoebae in three North American East Coast salt marshes (Leipsic River marsh, Delaware, USA; Little River marsh, Maine, USA; and Little Dipper Harbour marsh, New Brunswick, Canada). Five zones are recognized in the high salt marsh. With increasing marine influence, these zones are characterized by the following succession of dominant taxa: Valkanovia elegans, Tracheleuglypha dentata, Centropyxis cassis type, C. platystoma type and Difflugia pristis type. Most species occur in all three marshes, and their general vertical distribution is comparable. The results are also comparable with those obtained from British salt marshes, suggesting that salt-marsh testate amoebae have similar distributions on both sides of the Atlantic Ocean. The precision of the sea-level indicative value of testate amoebae in fossil salt-marsh sediments is a function of the local mean tidal range (MTR). Results of this study show that testate amoebae can indicate former sea levels with a precision of $\pm 0.04 \mathrm{~m}$ in the Leipsic River marsh $($ MTR $=1.75 \mathrm{~m}), \pm 0.09 \mathrm{~m}$ in the Little River marsh $($ MTR $=2.6 \mathrm{~m})$, and $\pm 0.18 \mathrm{~m}$ in the Little Dipper marsh $($ MTR $=5.8 \mathrm{~m})$.
\end{abstract}

\section{INTRODUCTION}

Testate amoebae (sometimes referred to as "thecamoebians", "arcellaceans", "rhizopods" or "testaceans") are a group of test-forming protozoans that have been documented in many freshwater environments. A few species have also been found in salt marshes by micropaleontologists who were interested in the distribution of benthic foraminifera. Only the larger $(>63 \mu \mathrm{m})$ testate amoebae were recorded in these studies, because the size fraction $63-500 \mu \mathrm{m}$ is commonly used for foraminiferal analyses. In peatlands, however, smaller testate amoebae $(15-63 \mu \mathrm{m})$ form the majority of the testate amoebae population. Charman and others (1998) analyzed samples from a salt marsh in south Wales and demonstrated the presence of testate amoebae using techniques that are common in peatland studies, including analysis of the size fraction 15-300 $\mu \mathrm{m}$. It was found that analyses of the smaller size fraction revealed a much higher diversity of the testate amoebae population: only two taxa occurred in the larger fraction compared to 36 taxa in the smaller fraction. Abundance increased from $\sim 100$ to up to 65,600 individuals per $\mathrm{cm}^{3}$ in the smaller size fraction. The significance of these findings was subsequently verified and confirmed in two other salt marshes in the United Kingdom, one on the

\footnotetext{
${ }^{1}$ School of Geography, University of Plymouth, Drake Circus, Plymouth,PL48AA, United Kingdom. Email:wrgehrels@plymouth.ac.uk

${ }^{2}$ School of Geography, Archaeology and Environmental Resources, Department of Geography, University of Exeter, Amory Building, Rennes Drive, Exeter, EX4 4RJ, United Kingdom.
}

Channel coast and one on the North Sea coast (Gehrels and others, 2001; Charman and others, 2002).

The occurrences of testate amoebae in the three British salt marshes have important implications for intertidal paleoecological studies and sea-level studies in particular. Charman and others (2002) demonstrated that salt-marsh testate amoebae occur in narrowly defined vertical zones in the supratidal and upper intertidal portions of salt marshes, as low as halfway between mean high water of spring tides (MHWS) and the highest astronomical tide (HAT) level. They can tolerate low levels of salinity (generally $0-5$ psu, but occasionally as high as $13 \mathrm{psu}$ ). Salinity and particle size appear to affect species composition, but the strongest controls on the distribution of testate amoebae in these salt marshes are flooding duration and height above mean tide level (Gehrels and others, 2001). These relationships imply that, like foraminifera (Scott and Medioli, 1978), fossil testate amoebae offer great potential as precise indicators of sea-level change in fossil intertidal sediments. Further investigations of salt-marsh testate amoebae are therefore desirable, and this paper represents the first documentation of small $(<63 \mu \mathrm{m})$ testate amoebae in North American salt marshes.

\section{SITE DESCRIPTIONS}

We sampled three salt marshes, one in the Bay of Fundy, one in the Gulf of Maine and one in Delaware Bay (Fig. 1). The Little Dipper Harbour marsh, in New Brunswick, Canada, is a small salt marsh $(\sim 20$ ha), which evolved behind a sand spit on the northern shore of the Bay of Fundy. The coast here is macrotidal, with a mean tidal range of about $5.8 \mathrm{~m}$ (Hydrographer of the Navy, 2000). The Little River marsh (Kelley and others, 1995) along the southwestern coast of Maine, USA, is also a backbarrier salt marsh, about twice the size of the Little Dipper Harbour marsh. The mean tidal range in this part of the Gulf of Maine is about $2.6 \mathrm{~m}$ (Hydrographer of the Navy, 2000). In Delaware, we sampled a transect across the Leipsic River marsh, an extensive marsh area in northwestern Delaware Bay where the mean tidal range is about $1.75 \mathrm{~m}$ (Nikitina and others, 2000).

We sampled the upper centimeter of the surface sediment along transects that followed the elevational gradient of the marshes. Because the environmental parameter of primary interest was height above mean tide level, we sampled with a vertical resolution of $5-10 \mathrm{~cm}$ or less. All sites were surveyed with a Total Survey Station and tied in with nearby geodetic benchmarks and tidal datums.

\section{SAMPLE PREPARATION}

Testate amoebae samples were prepared using a modified version of a standard method (Hendon and Charman, 


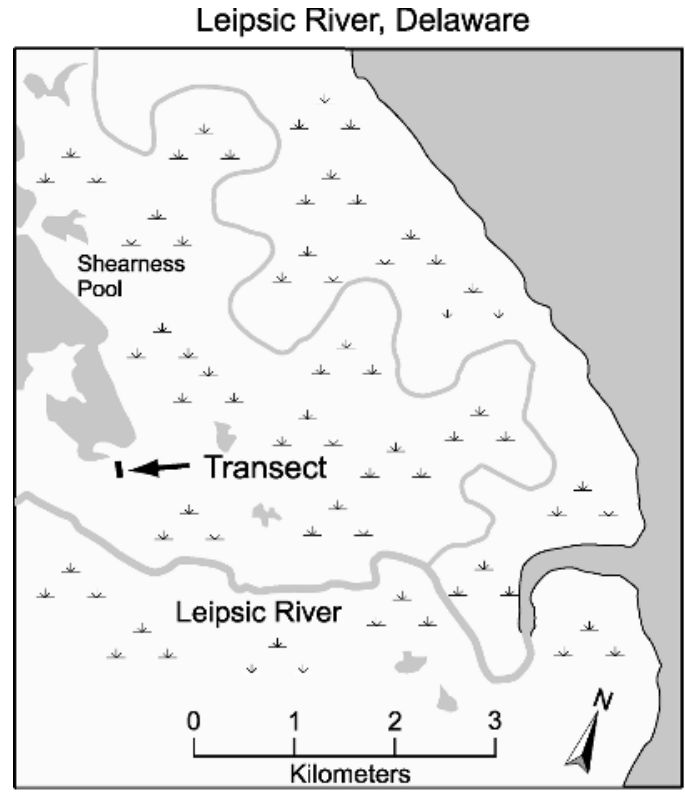

Wells, Maine

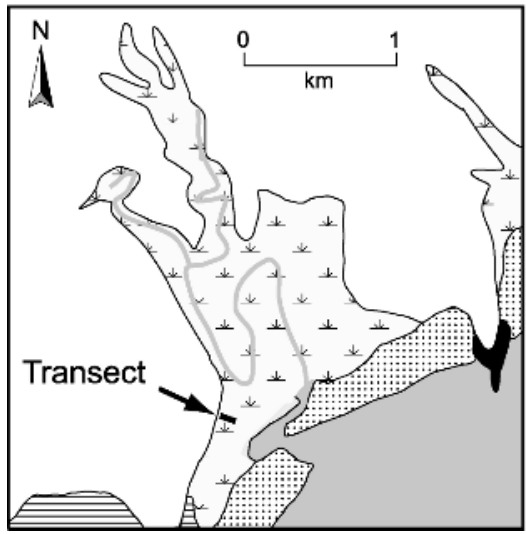

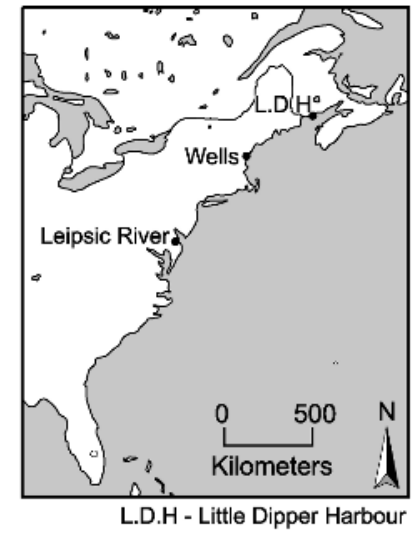

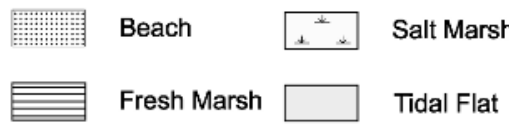

$\square$ Rock Water

FIGURE 1. Location map of sampled transects in three North American East Coast salt marshes.

1997). Sediment samples of about $5 \mathrm{~cm}^{3}$ were weighed, and two Lycopodium clavatum L. tablets (Stockmarr, 1971) were added to each sample to enable estimates of concentration. Samples were simmered close to boiling temperature for ten minutes in $100 \mathrm{ml}$ of distilled water to disaggregate the sediment. Heating is not always necessary but in clayey samples, it facilitates disaggregation. Heating for short periods does not affect the preservation of the testate amoebae (Hendon and Charman, 1997). Once cooled, the samples were sieved through a $300-\mu \mathrm{m}$ mesh and a $15-\mu \mathrm{m}$ mesh, with the fraction between 15-300 $\mu \mathrm{m}$ retained. This removes fine detritus, such as humic particles and clay- to silt-sized mineral grains and also removes the larger debris. Samples were not stained and were mounted in water rather than glycerol as this improves the optical quality of the slides and aids identification. Samples were mounted under a $22 \times 50 \mathrm{~mm}$ cover slip and were counted using a highpower light microscope (400-1000× magnification). Per sample, 150 tests were counted whenever possible, as this has been found to give samples with representative assemblages from peat samples (Warner, 1990; Woodland, 1996) and is a statistically acceptable practice when key indicator species are abundant (Patterson and Fishbein, 1989). Samples with fewer than 150 counts were excluded from statistical analyses.

\section{TAXONOMY}

Taxonomic descriptions are listed in Appendix 1. Detailed taxonomic information and criteria for separation of taxa are also provided in Charman and others (2000b), with additional taxa in Charman and others (1998, 2000a, 2002). Many of the identification criteria and names for these taxa are drawn from previous general keys such as those of Grospietsch (1958) and Corbet (1973). It should be noted that we regard all of the testate amoeba taxa as morphological types, rather than true biological species. For the purposes of making environmental inferences from 
taxon assemblages, it is important that as many morphological types as possible are maintained to prevent loss of potential information (Bobrov and others, 1999). However, it is equally important that identification criteria are repeatable by different workers and do not lead to an excessive amount of splitting. Thus, our taxonomy is intended to be a pragmatic approach. Where there are clear synonymies with a variety of possible specific names, we refer to these as 'types' rather than by specific names only. In cases where there is a high degree of consistency between authors and no obvious synonymies, we omit the 'type' suffix. The synonymies we refer to below are purely to enable comparisons with existing taxonomies applied in other studies of British salt marshes (Charman and others, 1998, 2002; Gehrels and others, 2001), North American salt-marsh and lacustrine environments, as well as with taxonomies applied in terrestrial peatland studies. Many taxa have not previously been reported for North American salt marshes, but we have commented on similar taxa described from lakes and have identified synonymies. For North American terrestrial peatlands, a similar taxonomy to the one we have applied here is commonly used (e.g., Booth, 2002).

One of the problems with making comparisons between taxonomies used in "foraminifera-based" studies and those using "pollen-based" approaches (Hendon and Charman, 1997 ) is that the observations are made in a fundamentally different way. In the former, the larger size fraction $(>45 \mu \mathrm{m}$ or $>63 \mu \mathrm{m})$ is observed under a low-power dissecting microscope, allowing specimens to be turned and observed easily in three dimensions. In the latter, all material $>15 \mu \mathrm{m}$ is observed under higher magnification using glass slides and coverslips. This provides only limited visibility of all dimensions. Photographs shown here were all taken under a light microscope as this is the normal method used for counting these relatively small taxa.

\section{RESULTS}

In Figure 2 we present data for the most abundant testate amoebae we encountered at the three sites. All 17 samples from the Little River marsh, Maine, had sufficient concentrations of testate amoebae. Twelve of 21 samples from Little Dipper Harbour marsh, New Brunswick, had sufficient numbers, compared to only nine of 25 samples from Leipsic River, Delaware. In Appendix 2 we only list the samples that contain testate amoebae.

In the Little River marsh, testate amoebae were found in the upper vertical meter of the transect, between $1.49 \mathrm{~m}$ and $2.54 \mathrm{~m}$ above NGVD (National Geodetic Vertical Datum; mean high water occurs here at $1.43 \mathrm{~m}$ above NGVD). Seventeen samples yielded a total of 22 taxa. The testate amoebae distribution shows a clear vertical zonation. The taxa Valkovia elegans (18-28\% of population) and Cyclopyxis arcelloides type (13-22\%) are important species near the top of the transect. In the middle of the transect, Centropyxis cassis type (14-46\%) and Centropyxis aculeata type $(8-56 \%)$ are dominant. Centropyxis platystoma type $(16-43 \%)$ and Difflugia pristis type $(38-51 \%)$ are the taxa that are most tolerant to submergence by saline waters.
These two species constitute virtually the entire population at the low end of the transect.

A total number of 18 taxa were identified in the samples from the Little Dipper Harbour marsh in New Brunswick. For comparative purposes we present the data relative to NGVD (Fig. 2), although this datum is not used in Canada. The Canadian Geodetic Datum in Little Dipper Harbour is approximately $0.27 \mathrm{~m}$ above NGVD. Testate amoebae occur between $3.88 \mathrm{~m}$ (i.e., $\sim 0.5 \mathrm{~m}$ above MHWS) and $4.63 \mathrm{~m}$ above NGVD. The distribution of testate amoebae and the assemblage composition along the Little Dipper Harbour marsh transect are very similar to those in the Little River marsh. The main difference is that Centropyxis cassis type reaches higher abundances in New Brunswick compared to Maine (up to $91 \%$ ). It constitutes an almost monospecific assemblage along the middle part of the sampled transect. Hyalospheria subflava and Assulina seminulum are the only two taxa found in New Brunswick that were not encountered in the Maine samples. Euglypha tuberculata type and A. muscorum occur in higher abundances in the Little Dipper Harbour marsh than in the Little River marsh (up to $15 \%$ for both taxa). The five minor taxa that were found in Maine but not in New Brunswick are Difflugia kabylica type, Euglypha cristata, E. strigosa, Heleopera petricola and Cyphoderia ampulla.

Along the Delaware transect, very few samples contained sufficient testate amoebae. There is a $0.14-\mathrm{m}$ interval between 1.05 and $1.19 \mathrm{~m}$ above NGVD where samples were barren. Only 14 taxa were found between 1.00 and $1.19 \mathrm{~m}$ above NGVD (Appendix 2). All these taxa were also found in Maine and New Brunswick. Tidal levels in this marsh are not well established due to the absence of a nearby tide station (Nikitina and others, 2000), but the lowest level of testate amoebae is about $0.1 \mathrm{~m}$ below HAT.

\section{ANALYSES AND DISCUSSION}

We used several multivariate statistical methods to investigate the distribution of testate amoebae in the three North American salt marshes, with a particular focus on their value as sea-level indicators. The testate amoebae are unimodally distributed along the height gradient of the salt marshes, i.e., they have an optimal occurrence and their abundance drops off on either side of the optimum. This can be demonstrated by a detrended canonical correspondence analysis (DCCA) using the program CANOCO (Ter Braak, 1995). DCCA on the total testate amoebae data set from all three sites shows that the environmental gradient length is 3.13 standard deviation units. For data sets with gradient lengths greater than 2 standard deviation units, unimodal regression models (such as weighted averaging) are appropriate (Birks, 1995). We avoided linear regression models (such as partial least squares regression, or step-wise linear regression), because these are only appropriate for environmental gradient lengths below 2 standard deviation units.

We performed weighted averaging regression analysis using the program CALIBRATE (Juggins and Ter Braak, 1998) to calculate the correlation between the taxa and elevation, or the 'strength' of the intertidal zonation of testate amoebae (Table 1). Analyses were carried out for 


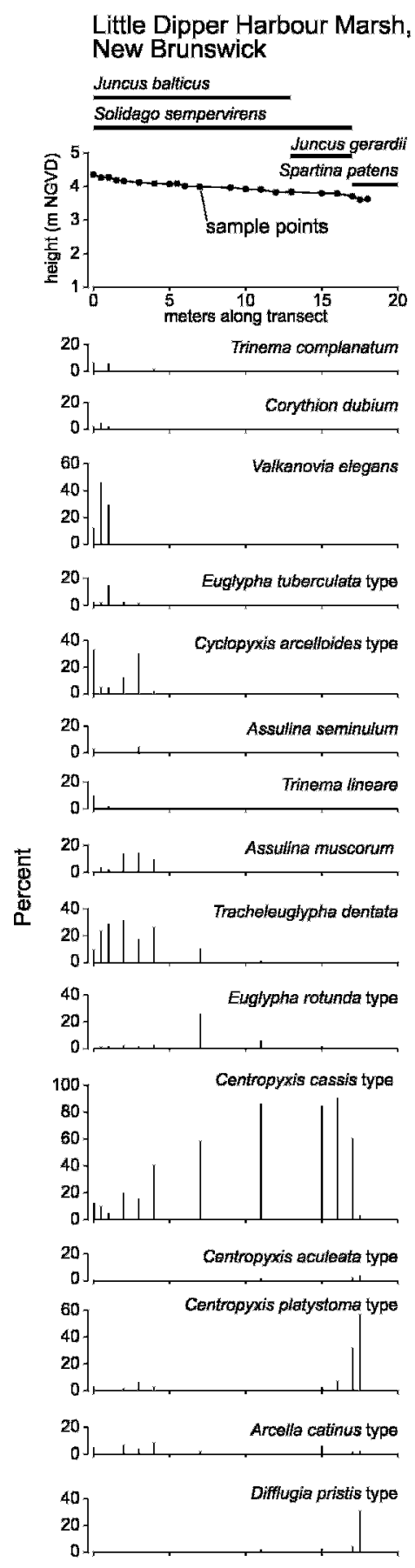

\section{Little River Marsh, Maine}
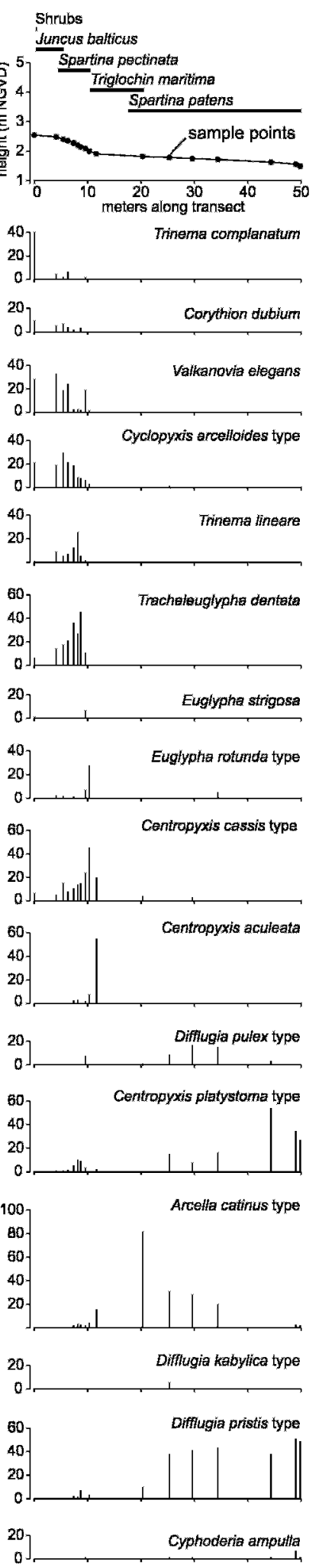
Leipsic River Marsh,
Delaware
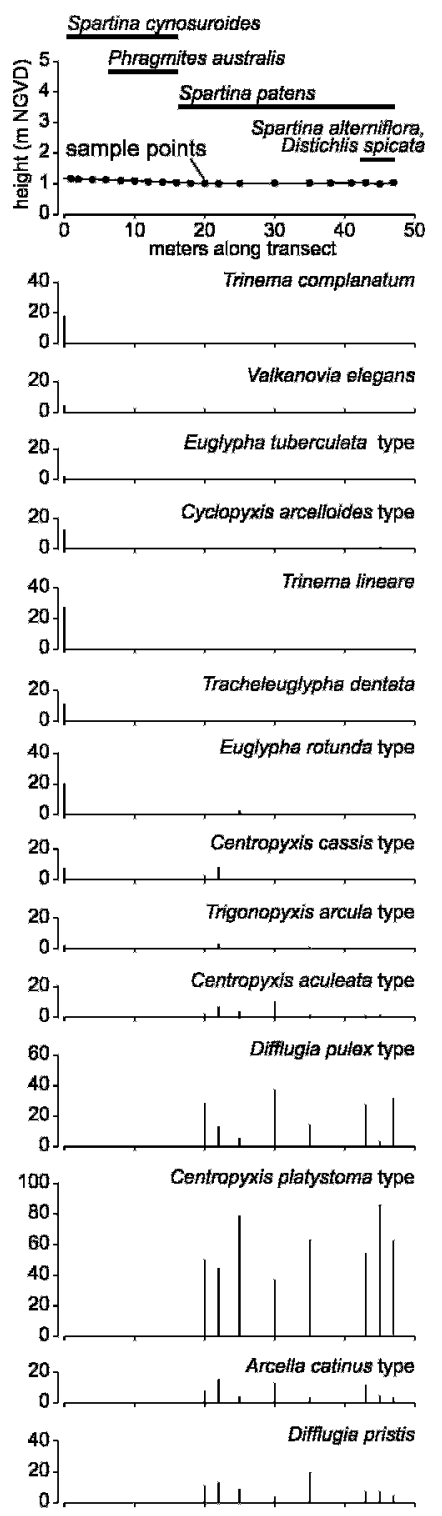

Figure 2. Distribution of testate amoebae along transects in three North American East Coast salt marshes. Taxa shown have occurrences of at least $4 \%$ in any given sample and are depicted together with the main plant species. Not all samples contained testate amoebae. Counts of samples containing testate amoebae are in Appendix 2. 
TABLE 1. Regression results on testate amoebae data from three North American East Coast salt marshes, based on a unimodal (weighted averaging) regression model (Juggins and Ter Braak, 1998). The combined data sets were normalized with respect to the vertical distance between HAT and MTL. The RMSEP (root mean squared error of prediction) is based on cross-validation by jack-knifing (Birks, 1995), which generally requires a minimum of 20 samples (Juggins, 2003). The local RMSEPs based on fewer than 20 samples are marked by an asterisk $(*)$.

\begin{tabular}{|c|c|c|c|c|c|c|}
\hline Training set & $\mathrm{N}$ & HAT (m NGVD) & MTL (m NGVD) & $\mathrm{r}^{2}$ & \multicolumn{2}{|c|}{$\operatorname{RMSEP}(\mathrm{m})$} \\
\hline Little River marsh & 17 & 2.19 & 0.10 & 0.93 & & $0.08^{*}$ \\
\hline Little Dipper Harbour marsh & 12 & 4.25 & 0.27 & 0.91 & & $0.07 *$ \\
\hline Leipsic River marsh & 9 & 1.11 & 0.19 & 0.97 & & $0.07 *$ \\
\hline Little River and Little Dipper & 29 & $\mathrm{n} / \mathrm{a}$ & $\mathrm{n} / \mathrm{a}$ & 0.84 & Little River & 0.11 \\
\hline Harbour marshes & & \multirow{4}{*}{$\mathrm{n} / \mathrm{a}$} & \multirow{4}{*}{$\mathrm{n} / \mathrm{a}$} & & Little Dipper Hbr. & 0.21 \\
\hline \multirow[t]{3}{*}{ All three sites combined } & \multirow[t]{3}{*}{38} & & & \multirow[t]{3}{*}{0.87} & Little River & 0.09 \\
\hline & & & & & Little Dipper Hbr. & 0.18 \\
\hline & & & & & Leipsic River & 0.04 \\
\hline
\end{tabular}

local training sets and for combinations of the three training sets. For the latter, the height data were standardized to account for differences in tidal range between the three study sites, converting heights to a $1 \mathrm{~m}$ vertical distance between mean tide level and HAT. The root mean square error of prediction (RMSEP) is the value that represents the uncertainty when the modern data set is used to predict sea level from fossil testate amoebae.
RMSEPs indicate that each local data set of testate amoebae has the capability to predict sea level with a precision of $\pm 0.07-0.08 \mathrm{~m}$, but these values are calculated from small training sets. A larger training set, combining the data sets from all three sites, produces errors of $\pm 0.04 \mathrm{~m}$ in the Leipsic River marsh, \pm 0.09 in the Little River marsh and $\pm 0.18 \mathrm{~m}$ in the Little Dipper Harbour marsh (Table 1). As may be expected, the precision of sea-

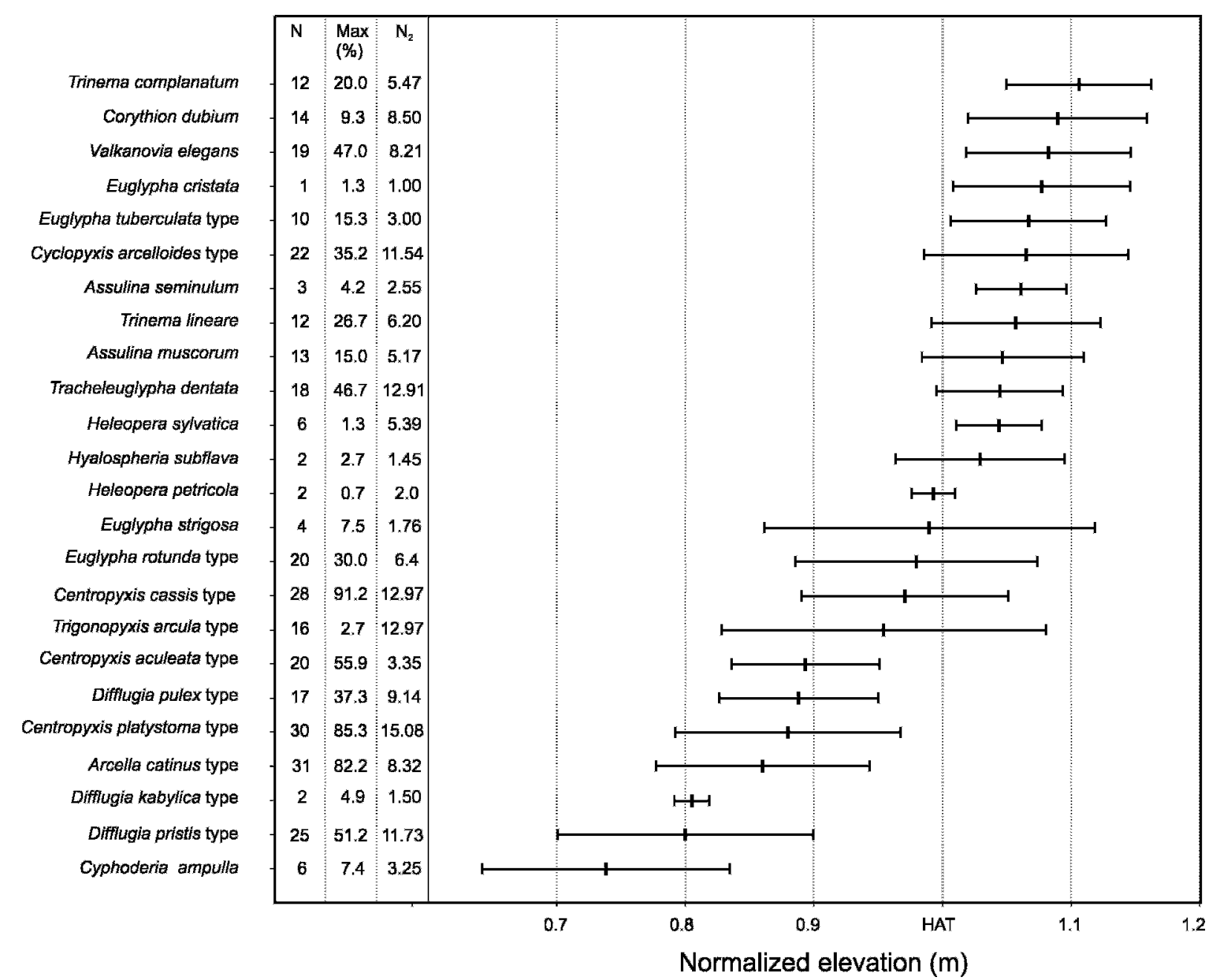

Figure 3. Heights of occurrences $( \pm 1 \sigma)$ of testate amoebae taxa in three North American East Coast salt marshes, calculated by unimodal regression. Heights were normalized to a standard vertical distance between mean tide level and the highest astronomical tide level to account for variable tidal ranges ( $\mathrm{N}$-number of occurrences, Max (\%)-maximum abundance, $\mathrm{N}_{2}$-Hill's diversity index). 


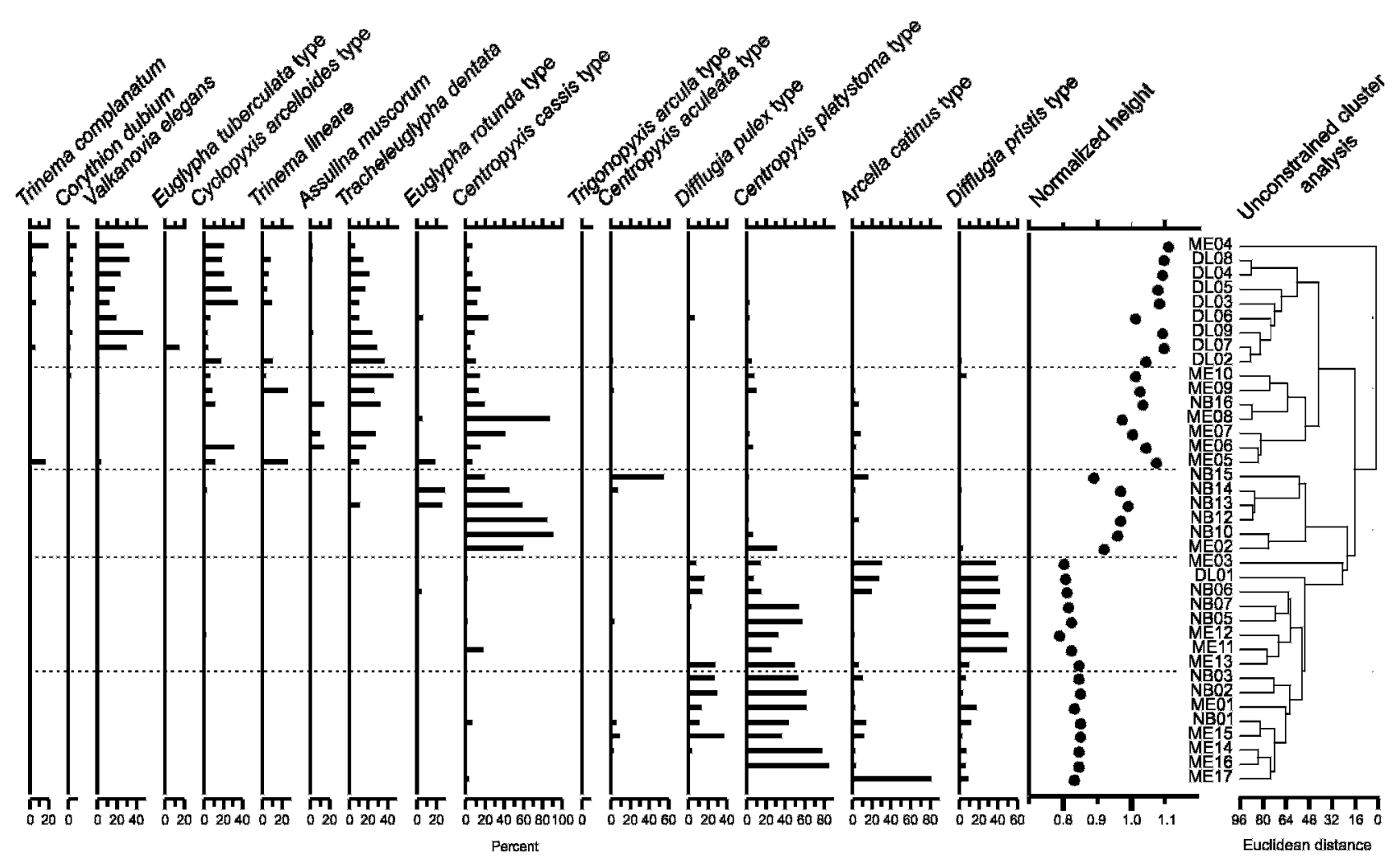

FIGURE 4. Unconstrained cluster analysis of testate amoebae samples from salt marshes in Maine (samples with prefix ME), New Brunswick (NB) and Delaware (DL). Five biozones are highlighted. Only species with at least 10 occurrences are shown. Sample codes are in Appendix 2.

level reconstructions would decrease in marshes with a higher tidal range.

We also used weighted averaging regression to calculate the optima and the ranges of the individual taxa. They are shown in Figure 3, together with the number of occurrences, the maximum abundance and Hill's diversity index. In decreasing number of occurrences, the primary taxa present in North American salt marshes are: Centropyxis platystoma type, Centropyxis cassis type, Cyclopyxis arcelloides type, Euglypha rotunda type, Difflugia pulex type and Trigonopyxis arcula type. Testate amoebae are only found in the high salt marsh; they are not found below the level of mean high water (in Wells, Maine) or below the level approximately halfway between MHWS and HAT (in Little Dipper Harbour and Leipsic River marshes). Important taxa that are most tolerant to tidal flooding are Difflugia pulex type, Arcella catinus type and Centropyxis platystoma type. Important taxa that have narrow vertical ranges and are, therefore, useful as sea-level indicators include Tracheleuglypha dentata, Centropyxis aculeata type and Difflugia pulex type.

We performed unconstrained cluster analysis using CANOCO (Ter Braak, 1995) to examine the zonation in more detail. In Figure 4 we highlight five biozones that are revealed by this type of statistical treatment. Samples from the higher elevations group in two clusters, the higher one characterized by Valkanovia elegans and the lower one by Tracheleuglypha dentata and Centropyxis cassis type. The lowest occurrences of these taxa define the boundaries of these two zones. The higher zone is best represented in the Delaware samples and the lower zone in the Maine samples.
A zone dominated by very high relative abundances of Centropyxis cassis type occurs in samples about halfway along the sampled height gradient. Most of these samples come from New Brunswick. The upper transition of this zone is the primary cluster boundary recognized by the cluster analysis. The lower boundary of this zone is defined by a sudden reduction of Centropyxis cassis type and the highest occurrences of Difflugia taxa.

Two clusters can be distinguished in the lowest samples, which consist of a mix of Maine and New Brunswick material. These two zones are dominated by Centropyxis platystoma type and Difflugia pristis type, respectively. Similar taxa are present in both zones, but their relative abundances differ markedly. The Difflugia pristis type biozone is the lowest found in the salt marshes.

Prior to this study, only in the United Kingdom has the distribution of small $(<63 \mu \mathrm{m})$ testate amoebae in salt marshes been investigated (Charman and others, 1998, 2000a; Gehrels and others, 2001; Charman and others, 2002). We find that the assemblages represented in British salt marshes and North American East Coast salt marshes are broadly similar. Major taxa that occur on both sides of the Atlantic Ocean include Euglypha tuberculata type, Cyclopyxis arcelloides type, Trinema lineare, Tracheleuglypha dentata, Euglypha rotunda type, Centropyxis cassis type, Centropyxis platystoma type and Difflugia pristis type. The vertical distribution of these species is also similar on both sides of the Atlantic. Euglypha tuberculata type, Trinema lineare and Tracheleuglypha dentata occur in the highest part of the salt marsh, whereas Centropyxis cassis type, Centropyxis platystoma type and Difflugia 

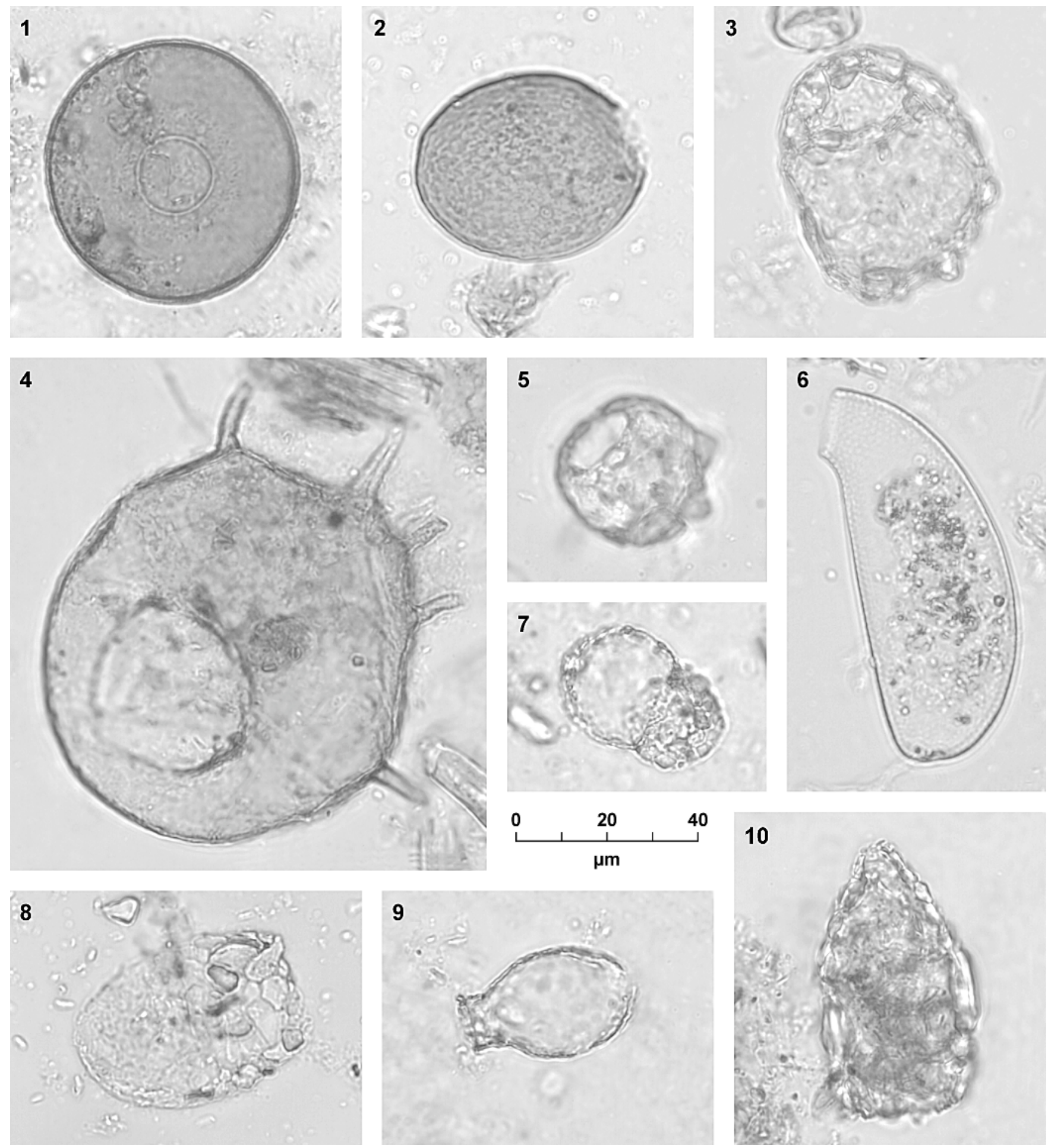

PLATE 1

Photomicrographs of the testate amoebae taxa. 1. Arcella catinus type, polar view. 2. Assulina muscorum, broad lateral view. 3. Centropyxis cassis type, broad lateral view. 4. Centropyxis aculeatea type, broad lateral view. 5. Cyclopyxis arcelloides type, oblique broad lateral view. 6 . Cyphoderia ampulla, broad lateral view. 7. Centropyxis platystoma type, broad lateral view. 8. Difflugia pristis type, broad lateral view. 9. Difflugia pulex type, broad lateral view. 10. Difflugia kabylica type, broad lateral view.

pristis type are found along the lower parts of the saltmarsh transects. Abundant species found in North America that were not found in UK marshes include the supratidal species Trinema complanatum and Valkanovia elegans, and the lower marsh species Difflugia pulex type and Arcella catinus type. Important species only recorded in UK salt marshes include the higher marsh species Trinema enchelys and Difflugia oblonga and the lower marsh species 

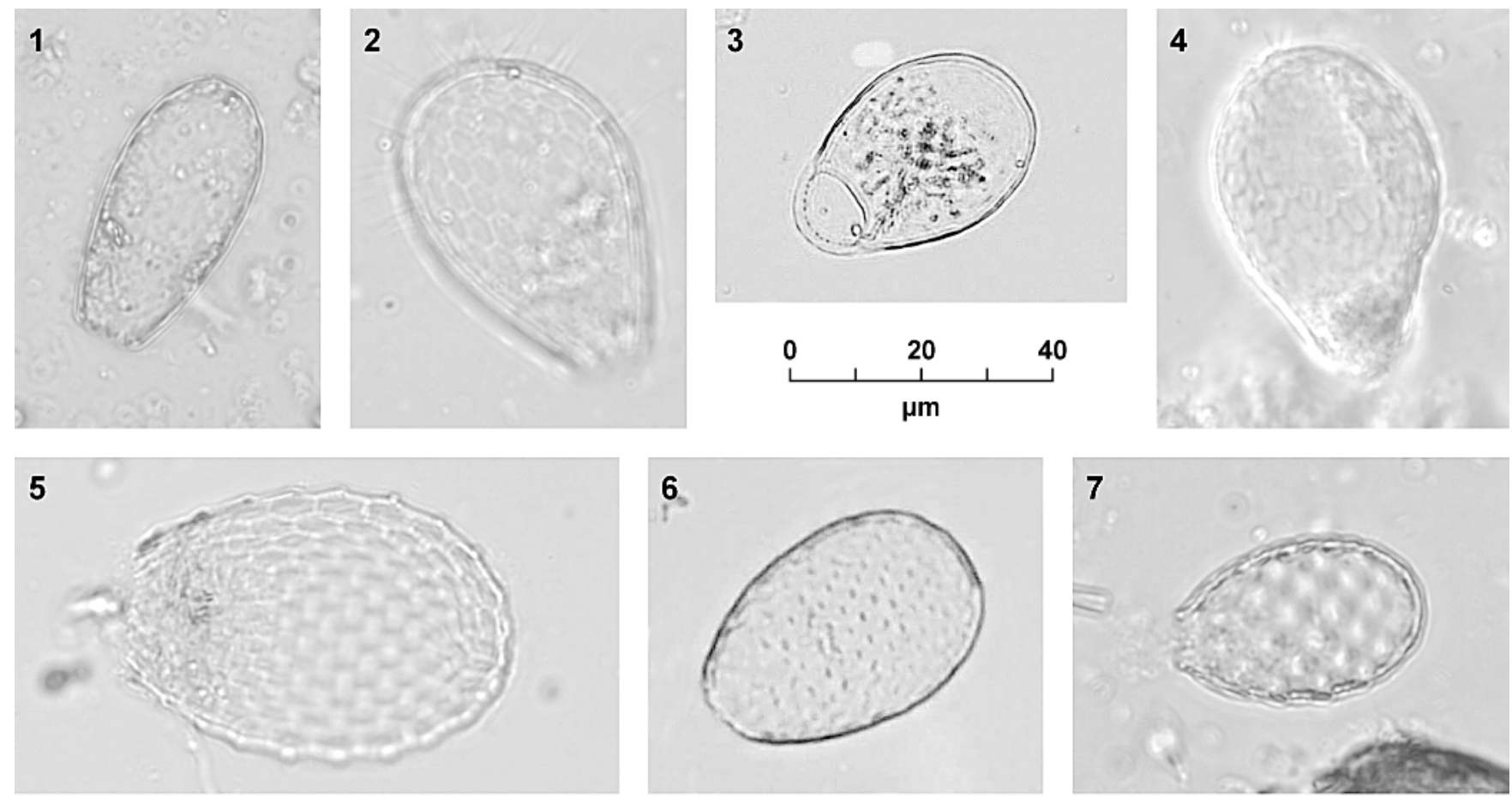

8

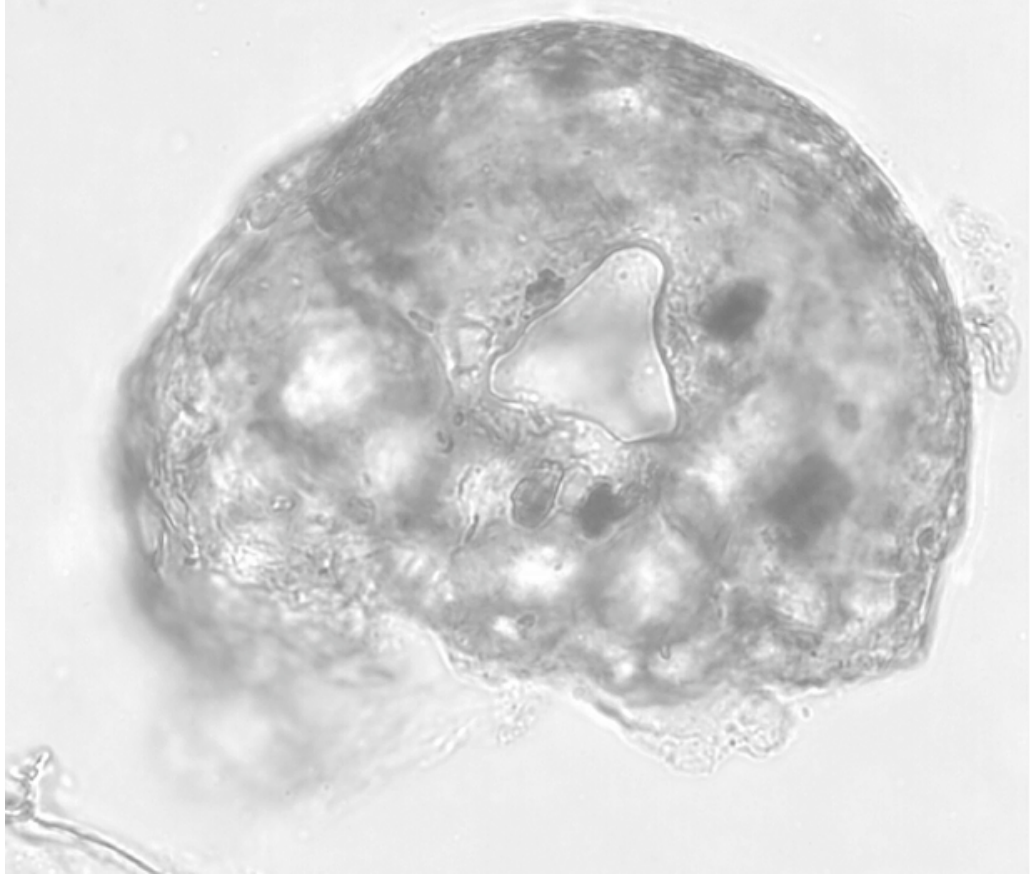

9

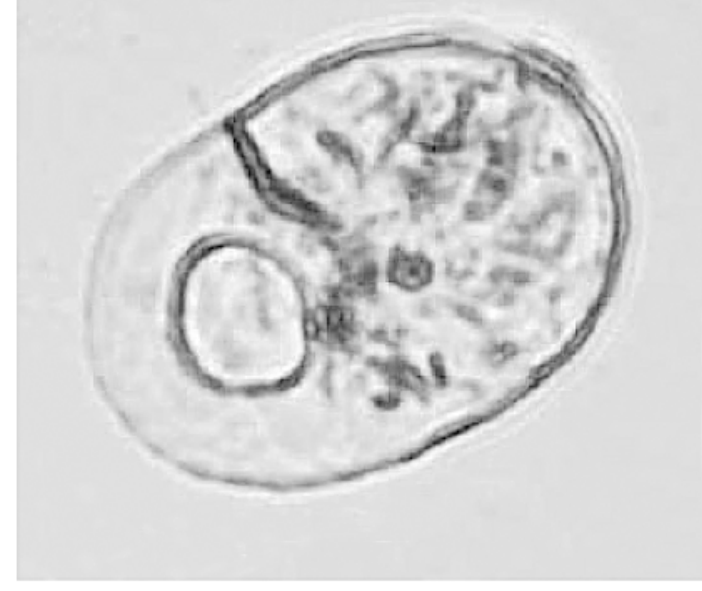

10a

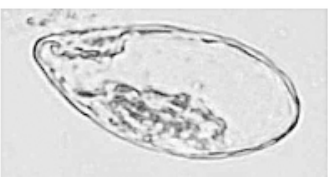

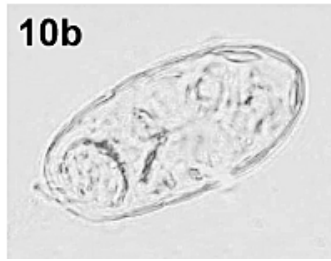

PLATE 2

Photomicrographs of the testate amoebae taxa. 1. Euglypha rotunda type, broad lateral view. 2. Euglypha strigosa, broad lateral view. 3. Corythion dubium, broad lateral view. 4. Euglypha cristata, broad lateral view. 5. Euglypha tuberculata type, broad lateral view. 6. Valkanovia elegans, broad lateral view. 7. Tracheleuglypha dentata, broad lateral view. 8. Trigonopyxis arcula type, polar view. 9. Trinema complanatum, broad lateral view. 10. Two views of Trinema lineare: (a) narrow lateral view and (b) broad lateral view.

Difflugia lucida. In both British and North American marshes, testate amoebae are found as low as halfway between MHWS and HAT. The only exception is the Little River marsh (Maine), where testate amoebae were found almost as low as the level of mean high water. The reasons for some variability in the occurrences of different taxa are yet unknown, but testate amoebae are sensitive to a range of environmental parameters (e.g., wetness, salinity, acidity and substrate; Charman, 2001; Charman and others, 2002). The influence of these parameters on the distribution of salt-marsh testate amoebae remains an area for future study. 
In UK salt marshes, Gehrels and others (2001) found $r^{2}$ values of $0.3-0.4$ for the relationship between testate amoebae taxa and elevation, considerably lower than in this study (Table 1). However, the value of $r^{2}$ is strongly depended on the length of the gradient. The RMSEP is a more useful parameter as it represents the precision of the sea-level indicative value of the assemblage. In a combined training set from three UK sites, the RMSEP based on testate amoebae varied between \pm 0.17 and $\pm 0.28 \mathrm{~m}$, improving to $\pm 0.07- \pm 0.18 \mathrm{~m}$ for local training sets (Gehrels and others, 2001). The North American intertidal testate amoebae zonation is, thus, comparable to that of British salt marshes (Table 1).

Future studies should investigate the occurrence and preservation of testate amoebae in fossil deposits. We scanned some samples from basal peat deposits of middle Holocene age collected from salt marshes in Maine and found testate amoebae to be present, but only in very low concentrations (Gehrels, unpublished data). More recent salt-marsh deposits (up to $\sim 200$ years in age) in short cores collected from the Little River marsh (Maine) contained well-preserved testate amoebae assemblages, similar to those found on the surface (Manning, 2003). In UK sediments from a range of coastal environments, Roe and others (2002) found that fossil testate amoebae were present, but they occurred in variable concentrations and a variable state of preservation. In some cases the fossil assemblage could not be matched to known modern assemblages. The best results were obtained from testate amoebae preserved in sediments from isolation basins and salt marshes (Roe and others, 2002).

It is clear that testate amoebae have potential as sea-level indicators if adequately preserved in sediments. Studies of fossil testate amoebae, including improved sample preparation techniques, are currently underway and show promising results (Manning, 2003; Charman, unpublished data). Currently, the most precise sea-level indicators in salt marshes along the North American East Coast are agglutinated foraminifera, which can indicate former sea levels with precisions generally ranging from \pm 0.15 $\pm 0.20 \mathrm{~m}$ in most salt marshes (Gehrels, 2000). Our findings indicate that testate amoebae could half this uncertainty.

\section{CONCLUSIONS}

We identified testate amoebae in samples from three North American East Coast salt marshes: the Little Dipper Harbour marsh in New Brunswick, Canada; the Little River marsh near Wells, Maine; and the Leipsic River marsh in Delaware. A total of 23 taxa were found in the size fraction 15-300 $\mu \mathrm{m}$; all but one occurred in the Maine salt marsh. The New Brunswick marsh harboured 18 taxa and the Delaware marsh 14. Five taxa were found exclusively in Maine and one exclusively in New Brunswick. With increasing tolerance to tidal flooding, important taxa include: Valkanovia elegans, Cyclopyxis arcelloides type, Tracheleuglypha dentata, Euglypha rotunda type, Centropyxis cassis type, Trigonopyxis arcula type, Centropyxis aculeata type, Difflugia pulex type, Centropyxis platystoma type, Arcella catinus type and Difflugia pristis type. The vertical distribution of the taxa in the Delaware, Maine and
New Brunswick marshes is comparable and strongly correlated with tidal elevation. Statistical analyses show that testate amoebae could indicate former sea levels with a precision of $\pm 0.04 \mathrm{~m}$ in the microtidal Leipsic River marsh, $\pm 0.09 \mathrm{~m}$ in the mesotidal Little River marsh and $\pm 0.18 \mathrm{~m}$ in the macrotidal Little Dipper marsh. There are many similarities between the testate amoebae distributions in salt marshes in Britain and salt marshes along the North American East Coast. We conclude that testate amoebae analysis is potentially a powerful tool for reconstructing sea-level changes from salt-marsh deposits on both sides of the North Atlantic Ocean.

\section{ACKNOWLEDGMENTS}

Funding for this project was provided by a Royal Society exchange grant to Canada and a British Council travel grant. WRG thanks the Pizzutos in Delaware and the Pattersons in Ottawa for their warm hospitality provided during his sabbatical visit in 1998. We are grateful to the people who helped with fieldwork: Dan Belknap, Scott Hippensteel, Roy Patterson, Tim Patterson, Daria Nikitina, Jim Pizzuto, Reed Schwimmer and Ellen Tobey. Tim Absalom and Jamie Quinn assisted with the preparation of figures and plates. Ed Reinhardt and Tim Patterson provided very helpful reviews. This paper is a contribution to IGCP Project 495 (Quaternary Land-Ocean Interactions: Driving Mechanisms and Coastal Responses).

\section{REFERENCES}

BIRKS, H. J. B., 1995, Quantitative palaeoenvironmental reconstructions. Chapter 6, in Maddy, D., and Brew, J. S. (eds.), Statistical Modelling of Quaternary Science Data: Technical Guide 5, Quaternary Research Association, Cambridge, p. 161-254.

Bobrov, A. A., Charman, D. J., and Warner, B. G., 1999, Ecology of testate amoebae (Protozoa: Rhizopoda) on peatlands in western Russia with special attention to niche separation in closely related taxa: Protist, v. 150, p. 125-136.

Boотн, R. K., 2002, Testate amoebae as paleoindicators of surfacemoisture changes on Michigan peatlands: modern ecology and hydrological calibration: Journal of Paleolimnology, v. 28, p. 329-348.

CAsh, J., and Hopkinson, J., 1909, The British Freshwater Rhizopoda and Helizoa. Vol. II, Rhizopoda part 2: The Ray Society, London, $156 \mathrm{p}$.

Charman, D. J., 2001, Biostratigraphical and palaeoenvironmental applications of testate amoebae: Quaternary Science Reviews, v. 20 , p. $1753-1764$.

- Gehrels, W. R., and Roe, H. M., 2000a, The use of $<63 \mu \mathrm{m}$ fractions in the separation and identification of testate amoebae in the inter-tidal zone, in Hart, M. B., Kaminski, M. A., and Smart, C. (eds.), Proceedings of the Fifth International Workshop on Agglutinated Foraminifera: Grzybowski Foundation Special Publication, v. 7, p. 89-99.

- Hendon, D., and Woodland, W. A., 2000b, The identification of testate amoebae (Protozoa: Rhizopoda) in peats: Quaternary Research Association Technical Guide No. 9, 147 p.

, Roe, H. M., and Gehrels, W. R., 2002, Saltmarsh testate amoebae and sea level: zonation and response to environmental variables: Journal of Quaternary Science, v. 17, p. 387-409.

- $\longrightarrow$, and 1998, The use of testate amoebae in studies of sea-level change: a case study from the Taf estuary, South Wales, UK: The Holocene, v. 8, p. 209-218.

Corbet, S. A., 1973, An illustrated introduction to the testate rhizopods in Sphagnum, with special reference to the area around Malham Tarn, Yorkshire: Field Studies, v. 3, p. 301-322. 
Deflandre, G., 1929, Le genre Centropyxis Stein: Archiv für Protistenkunde, v. 67, p. 323-375.

Dujardin, F., 1841, Histoire Naturelle des Zoophytes: De Roret, Paris, $684 \mathrm{p}$.

EhrenberG, C. G., 1830, Organisation, Systematik und geographisches Verhältnis der Infusionsthierchen: Druckerei der Königlichen Akademie der Wissenschaften, Berlin, $108 \mathrm{p}$.

- 1831 , Über die Entwicklung und Lebensdauer der Infusionsthiere, nebst ferneren Beiträgen zu einer Vergleichung ihrer organischen Systeme: Königliche Akademie der Wissenschaften zu Berlin Abhandlungen, Physikalische Abhandlungen, p. 1-154.

— 1840 , Das grössere Infusorienwerke: Könligliche Akademie der Wissenschaften zu Berlin Abhandlungen Physikalische Abhandlungen, p. 198-219.

— 1848, Fortgesetzte Beobachtungen über jetzt herrschende atmosphärische mikroskopische Verhältnisse. Bericht über die zur Bekanntmachung geeigneten: Verhandlungen der Königlichen Preussischen Akademie der Wissenschaften zu Berlin, v. 13, p. $370-381$.

L 1872 , Nachtrag zur Übersicht der organischen Atmosphärilen: Königliche Akademie der Wissenschaften zu Berlin, Physikalische Abhandlungen 1871, p. 1-150, p. 233-275.

Gauthier-Lièvre, L., and Thomas, R., 1958, Les genres Difflugia, Pentagonia, Maghrebia et Hoogenraadia (Rhizopdes testacés) en Afrique: Archiv für Protistenkunde, v. 103, p. 241-370.

Gehrels, W. R., 2000, Using foraminiferal transfer functions to produce high-resolution sea-level records from saltmarsh deposits, Maine, USA: The Holocene, v. 10, p. 367-376.

- Roe, H. M., and Charman, D. J., 2001, Foraminifera, testate amoebae and diatoms as sea-level indicators in UK saltmarshes: a quantitative multiproxy approach: Journal of Quaternary Science, v. 16, p. 201-220.

GreefF, R., 1888, Studien über Protozoen: Sitzungsberichte der Gesellschaft zur Beförderung der gesammten Naturwissenschaften zu Marburg, v. 3, p. 90-158.

Grospietsch, T., 1958, Wechseltierchen (Rhizopoden): Kosmos, Stuttgart, $82 \mathrm{p}$.

Hendon, D., and Charman, D. J., 1997, The preparation of testate amoebae (Protozoa: Rhizopoda) samples from peat: The Holocene, v. 7, p. 199-205.

Hydrographer of THE NAvy, 2000, Admiralty Tide Tables Volume 22001: Europe (excluding United Kingdom and Ireland), Mediterranean Sea and Atlantic Ocean: U.K. Hydrographic Office, Taunton, $474 \mathrm{p}$.

Juggins, S., and Ter BraAk, C. J. F., 1998, CALIBRATE Version 0.82. A Computer Program for the Graphical Display and Analysis of Species/Environment Relationships by Weighted Averaging, [Weighted Averaging] Partial Least Squares and Principal Components Analysis: Department of Geography, University of Newcastle, Newcastle-Upon-Tyne, $69 \mathrm{p}$.

$\ldots, 2003, \mathrm{C}^{2}$ User Guide. Software for ecological and palaeoecological data analysis and visualisation: University of Newcastle, Newcastle-Upon-Tyne, $69 \mathrm{p}$.

Kelley, J. T., Gehrels, W. R., and Belknap, D. F., 1995, Late Holocene relative sea-level rise and the geologic development of tidal marshes at Wells, Maine, U.S.A.: Journal of Coastal Research, v. 11, p. 136-153.

Kumar, A., and Dalby, A. P., 1998, Identification key for Holocene lacustrine arcellacean (Thecamoebian) taxa: Paleontologica Electronica, v. 1, 34 p., 3.1MB, http://www.odp.tamu.edu/paleo/1998_ 1/toc.htm

LEIDY, J., 1874, Notice on some Rhizopoda: Academy of Natural Sciences of Philadelphia, Proceedings, ser. 3, p. 155-157.

- 1878, Species of Euglypha, Trinema, Pamphagus and Cyphoderia: Academy of Natural Sciences of Philadelphia, Proceedings, p. 171-173.

, 1879, Freshwater Rhizopods of North America: U.S. Geological Survey of the Territories, v. 12, $324 \mathrm{p}$.
Manning, C. E., 2003, Developing testate amoebae analyses for reconstructing late Holocene sea-level change in the Gulf of Maine, USA: Unpublished M.Sc. thesis, University of Plymouth, $57 \mathrm{p}$.

Medioli, F. S., and ScotT, D. B., 1983, Holocene arcellacea (Thecamoebians) from Eastern Canada: Cushman Foundation Special Publication, no. 21, 63 p.

Nikitina, D. L., Pizzuto, J. E., Schwimmer, R. A., and Ramsey, K. W., 2000, An updated Holocene sea-level curve for the Delaware coast: Marine Geology, v. 171, p. 7-20.

Patterson, R. T., and Fishbein, E., 1989, Re-examination of the statistical methods used to determine the number of point counts needed for micropaleontological quantitative research: Journal of Paleontology, v. 63, p. 245-248.

Penard, E., 1890, Étude sur les Rhizopodes d'eau douce: Mémoires de la Société de Physique et d'Histoire Naturelle de Genève, v. 31, p. $1-230$.

, 1902, Faune Rhizopodique du Bassin du Léman: Henry Kündig, Genève, $714 \mathrm{p}$.

- 1912, Notes sur quelques Sarcodinés: Revue Suisse de Zoologie, v. 20, p. 1-29.

Reinhardt, E. G., Dalby, A., Kumar, A., and Patterson, R. T., 1998, Utility of Arcellacean morphotypic variants as pollution indicators in mine tailing contaminated lakes near Cobalt, Ontario, Canada: Micropaleontology, v. 44, p. 131-148.

Roe, H. M., Charman, D. J., and Gehrels, W. R., 2002, Fossil testate amoebae in coastal deposits in the UK: implications for studies of sea-level change: Journal of Quaternary Science, v. 17, p. 411-429.

Schönborn, W., and Peschke, T., 1990, Evolutionary studies on the Assulina-Valkanovia complex (Rhizopoda: Testaceafiliosea) in Sphagnum and soils: Biology and Fertility of Soils, v. 9, p. 95-100.

Scott, D. B., and Medioli, F. S., 1978, Vertical zonation of marsh foraminifera as accurate indicators of former sea-levels: Nature, v. 272 , p. $538-541$.

$\longrightarrow$, and $\longrightarrow$ 1983, Agglutinated rhizopods in Lake Erie: modern distribution and stratigraphic implications: Journal of Paleontology, v. 57, p. 809-820.

Stockmarr, J., 1971, Tablets with spores used in absolute pollen analysis: Pollen et Spore, v. 13, p. 615-621.

TARANEK, K. J., 1881, Beiträge zur Kenntniss der SüsswasserRhizopoden Böhmens: Sitzungsbericht Bölmischer Gesellschaften Wissenschaften, p. 220-235.

TER BRAAK, C. J. F., 1995, Ordination. Chapter 5, in Jongman, R. H. G., ter Braak, C. J. F., and van Tongeren, O. F. R. (eds.), Data Analysis in Community and Landscape Ecology: Cambridge University Press, Cambridge, UK, p. 91-173.

Von Stein, S. F. N., 1859, Über die ihm aus eigener Untersuchung bekannt gewordenen Süsswasser-Rhizopoden: Königliche Böhmishe Gesellschaft der Wissenschaften Abhandlungen, ser. 5, v. 10, p. $41-43$.

WALLICH, G. C., 1864, On the extent and some of the principal causes of structural variation among the Difflugian rhizopods: Annals and Magazine of Natural History, ser. 3, v. 13, p. 215-245.

Wailes, G. H., and Penard, E., 1911, Clare Island Survey: Rhizopoda: Proceedings of the Royal Irish Academy, v. 31, p. $1-64$.

Warner, B. G., 1990, Testate Amoebae (Protozoa). Methods in Quaternary ecology: Geoscience, Canada, v. 5, p. 65-74.

Woodland, W. A., 1996, Holocene palaeohydrology from testate amoebae analysis: developing a model for UK peatlands: Unpublished Ph.D. thesis, University of Plymouth, $420 \mathrm{p}$. 


\section{APPENDIX 1}

\section{Taxonomic Descriptions}

Arcella catinus Penard 1890 type (PI. 1, Fig. 1)

Arcella catinus Penard 1890, p. 154-155, Pl. 5, Fig. 78-92

Arcella catinus type Charman and others 2000b, p. 57-58, Fig. 8a-d, 9a

Charman and others (2000b) suggest that this taxon is primarily thought to relate to A catinus Penard 1890, but it may also include a number of other taxa which are impossible to separate during routine counting. There is a clear ring of pores around the mouth, and a circular to irregular test outline. Tests found are usually $50-120 \mu \mathrm{m}$ in diameter, dark brown and composed of smooth proteinaceous material. This taxon is possibly synonymous with $A$. vulgaris Ehrenberg 1830 of Kumar and Dalby (1998, Fig. 2-1), but A. catinus has pores around the mouth.

\section{Assulina muscorum Greeff 1888 (PI. 1, Fig. 2)}

Assulina muscorum Greeff 1888, p. 117-118

Assulina muscorum Charman and others 2000b, p. 81, Fig. 19a

Assulina minor Penard 1890, p. 23, Pl. 9, Fig. 14-25

Idiosomic test composed of overlapping oval plates with organic cement around the collar. Consistently brown-pink in color. 35-60 $\times$ 25-40 $\mu \mathrm{m}$ dimensions in broad lateral view.

\section{Assulina seminulum (Ehrenburg 1848) Leidy 1879}

Difflugia seminulum Ehrenberg 1848, p. 379

Assulina seminulum Leidy 1879 , p. 225-226, Pl. 37, Fig. 15-27

Assulina seminulum Charman and others, 2000b, p. 82, Fig. 19b-c

Similar to A.muscorum but distinguished from that taxon by larger size and more oval to circular shape in broad lateral view. 65-105 $\times$ 60-75 $\mu \mathrm{m}$. Mostly brown, sometimes colorless.

\section{Valkanovia elegans Schönborn and Peschke 1990}

Valkanovia elegans Schönborn and Peschke 1990, Fig.1, Table 1

Similar to Assulina taxa, Valkanovia elegans is distinguished from $A$. muscorum because it is "colorless and has a thin, more or less smooth aperture rim" (Schönborn and Peschke, 1990, p. 100). Like Bobrov and others (1999), we have found $V$. elegans to be mostly smaller than A. muscorum

\section{Centropyxis aculeata (Ehrenberg, 1830) von Stein 1859 type (PI. 1,}

Fig. 4)

Arcella aculeata Ehrenberg 1830, p. 40

Centropyxis aculeata von Stein 1859, p. 43

Centropyxis aculeata type Charman and others 2000b, p. 62-64,

Fig. $11 \mathrm{a}-\mathrm{b}$

Centropyxis aculeata "aculeata" Kumar and Dalby 1998, Fig 4-1

Similar to other taxa in the Centropyxis group (see below), and mainly distinguished by the presence of spines in a single plane. In North American lakes it has been divided into three "strains", $C$. aculeata "aculeata", C. constricta "constricta" and C. constricta "spinosa", mainly on the basis of the degree of flattening of the test and the number of spines (Kumar and Dalby, 1998, Figs. 4-1, 6-1, $6-2$, respectively). These more subtle distinctions are not made here, but most of our specimens probably fall within $C$. aculeata "aculeata" of Kumar and Dalby (1998). The test is ovoid or circular in broad lateral view. In narrow lateral view the test tapers towards the aperture. Usually amber-brown, the test is composed of proteinaceous material, sometimes with quartz particles on the surface. The aperture is sub-terminal, oval and $32-64 \mu \mathrm{m}$ in diameter. Centropyxis aculeata type has a variable number of spines, which are always in a single plane.

\section{Centropyxis cassis Deflandre 1929 type (Pl. 1, Fig. 3)}

Centropyxis cassis Deflandre 1929, p. 335-337, Fig. 35-40

Centropyxis cassis type Charman and others 2000b, p. 64-65, Fig. 12a

This taxon is distinguished from C. platystoma type (below) on the basis of shape in broad lateral view. This is the most frequent orientation of specimens on the slide. Centropyxis cassis type has a length:breadth ratio of $<2: 1$ whereas $C$. platystoma type has a length:breadth ratio $>2: 1$ (Charman and others, 2000). Both taxa would fall within C. constricta (Medioli and Scott, 1983, p. 41-43, Fig. 12, Pl. 7, Fig. 1-9), within Cucurbitella constricta (sic, in error,
Reinhardt, Communication, 2003; Reinhardt and others, 1998, Pl. 1, Fig 6) and within Centropyxis constricta 'aerophila' (Kumar and Dalby, 1998, Fig. 5-1). Centropyxis cassis type is $62-82 \mu \mathrm{m}$ length $\times 48-67 \mu \mathrm{m}$ breadth. In broad lateral view the test sides are parallel to convex and become semicircular at both poles. The test tapers towards the apertural region in narrow lateral view. The tests are colorless to brown, and composed of proteinaceous material and covered in quartz grains to produce a rough surface. The aperture is subterminal, semicircular and surrounded by particles to give an untidy appearance.

Centropyxis platystoma Deflandre 1929 type (PI. 1, Fig. 7)

Centropyxis platystoma Deflandre 1929, p. 338-340, Fig. 43-57

Centropyxis platystoma type Charman and others 2000b, p. 65-66, Fig. $12 \mathrm{~b}-12 \mathrm{c}$

Difflugia constricta Leidy 1879, Pl. 18, Fig. 20-21

Centropyxis constricta Medioli and Scott, 1983, p. 41-43, Fig. 12, Pl. 7, Fig. 1-9

Cucurbitella constricta (sic, in error, Reinhardt, Communication, 2003) Reinhardt and others, 1998, Pl. 1, Fig. 6

Centropyxis constricta 'aerophila' Kumar and Dalby, 1998, Fig. 5-1

See above for differences with $C$. cassis type.

Corythion dubium Taranek 1881 (PI. 2, Fig. 3)

Corythion dubium Taranek 1881, p. 232, Fig. 3

A small idiosomic taxon not previously reported for North American salt marshes or lakes. Charman and others (2000b) did not separate this from a related genus (Trinema) and described the taxon Corythion-Trinema Taranek 1881 type. Here, we separated $C$. dubium from two Trinema taxa because the plates were always clearly visible. The test is a flattened oval with a subterminal aperture, sometimes with teeth visible around the inside of the rim. The taxon is variable in size but generally $30-60 \mu \mathrm{m}$ long and $25-50 \mu \mathrm{m}$ wide.

Trinema complanatum Penard 1890 (PI. 2, Fig. 9)

Trinema complanatum Penard 1890, p. 187, Pl. 11, Fig. 1-4

A small idiosomic taxon similar to Corythion dubium in being a flattened ovoid test with a subterminal aperture. Also not previously reported for North American saltmarshes or lakes. The plates are less visible on the genus Trinema, but the shape of $T$. complanatum is characteristically evenly rounded oval with a smaller aperture than $C$. dubium. Typically $40-75 \mu \mathrm{m}$ long and $30-50 \mu \mathrm{m}$ wide.

\section{Trinema lineare Penard 1890 (PI. 2, Fig. 10)}

Trinema lineare Penard 1890, p. 187-188, Pl. 11, Fig. 5-17

Trinema lineare Charman and others 2000b, p. 107-108, Fig. 31b

Similar to Corythion dubium and Trinema complanatum, but smaller, less flattened and more elongate, with plates hardly ever visible. Typical size range is $15-40 \mu \mathrm{m}$ long and $7-20 \mu \mathrm{m}$ wide.

Cyclopyxis arcelloides (Penard 1902) Deflandre 1929 type (PI. 1, Fig. 5)

Centropyxis arcelloides Penard 1902, p. 309-310, Fig. 1-4

Cyclopyxis arcelloides Deflandre 1929, p. 367-368, Fig. 153-158

Cyclopyxis arcelloides type Charman and others 2000b, p. 66-68, Fig. 13a-13b

Difflugia globula Kumar and Dalby 1998, Fig. 23-1

Difflugia globulus Medioli and Scott 1983, p. 24-25, pl. 5, figs. 1-15

This is a highly variable taxon with a large size range (Charman and others, 2000b). During routine counting, it is not possible to separate distinctive classes based on size differences or morphological characteristics. Because of the absence of pseudopodia in fossil specimens, a number of Difflugia and Phryganella species are also inseparable from Cyclopyxis. Tests are circular in plan view and ovoid to hemispherical in lateral view. Test diameter varies between 35$110 \mu \mathrm{m}$. The tests are normally colorless and composed of mineral particles, organic matter and fungal hyphae. The aperture is central and sometimes invaginated. See Charman and others (2000, p. 66) for a more complete discussion of taxonomic problems associated with this taxon. Previous workers have placed similar tests within the genus Difflugia.

Cyphoderia ampulla (Ehrenberg 1840) Leidy 1878 (PI. 1, Fig. 6)

Difflugia ampulla Ehrenberg 1840, p. 199

Cyphoderia ampulla Leidy 1878, p. 173

Cyphoderia ampulla Leidy 1879, p. 202-204, Pl. 34, Fig. 1-16

Cyphoderia ampulla Gehrels and others, 2001, Fig. 4g 
Cyphoderia Ampulla Charman and others, 1998, Fig. 3b

Retort-shaped test with small circular plates described by many previous authors. Significant variability in size and sometimes in shape, from short, wide specimens to the more usual long, thin shape Typically $50-80 \mu \mathrm{m}$ long and $30-45 \mu \mathrm{m}$ wide. Not previously reported from North American salt marshes or lakes.

Difflugia kabylica Gauthier-Lièvre \& Thomas 1958 type (PI. 1, Fig. 10) Difflugia kabylica Gauthier-Lièvre \& Thomas 1958, p. 284-285, Fig. 17

An ovoid test with a circular aperture and pointed aboral region. Aperture with narrow collar with a recurved lip, composed of small mineral particles. Tests generally $40-80 \mu \mathrm{m}$ in length and $35-60 \mu \mathrm{m}$ in diameter with an aperture of around $20-25 \mu \mathrm{m}$ diameter. It is possible that this could be classified as part of the continuum of Difflugia pristis type (below) but has been distinguished from it in this study on the basis of the collar and pointed aboral region. Distinguished from $D$. acuminata type (Charman and others, 2000b) by smaller size and less elongated test. Also similar to D. protaeiformis "amphoralis" (Kumar and Dalby, 1998, Fig 14-1), but not tending to biconical shape as in this taxon.

\section{Difflugia pulex Penard 1902 type (PI. 1, Fig. 9)}

Difflugia pulex Penard 1902, p. 229-230, Fig. 1-5

Difflugia pulex type Charman and others 2000b, p. 78-79, Fig. 18b

A small pyriform taxon that is easy to miss on crowded slides, but it is consistent in size and shape and is therefore separated from the larger D. oblonga type (Charman and others, 2000b). Usually around $30 \mu \mathrm{m}$ or less in length, the test is colorless to brown in color and may have small siliceous particles giving the test an untidy surface appearance. Other similar taxa are Difflugia oblonga "oblonga" (Kumar and Dalby 1998 Fig 29-1), and Difflugia oblonga (Scott and Medioli 1983, p. 818, figs. $9 \mathrm{a}-\mathrm{b})$, but both these taxa are much larger and not so strongly pyriform as $D$. pulex type.

Difflugia pristis Penard 1902 type (Pl. 1, Fig. 8)

Difflugia pristis Penard 1902, p. 254-255, Fig. 1-4

Difflugia pristis type Charman and others 2000b, p. 77-78, Fig. $17 \mathrm{~b}-17 \mathrm{c}$

Tests are non-pyriform, ovoid, curved aborally and laterally compressed. Test dimensions are 40-60 × 30-40 $\mu \mathrm{m}$, with an aperture $25 \mu \mathrm{m}$ in diameter. Test construction is of smooth flat quartz particles and occasional diatom frustules. Non-pyriform taxa lacking distinctive constructions or acuminate shapes within the Difflugia are extremely confused in the literature but we have separated them into several size categories (Charman and others, 2000b). All of the specimens here fall into Difflugia pristis Penard 1902 type. D. pristis type would be included within D. oblonga of Scott and Medioli (1983). Also similar to Difflugia oblonga "glans" of Kumar and Dalby (1998, Fig 24-1).

Euglypha cristata Leidy 1874 (PI. 2, Fig. 4)

Euglypha cristata Leidy 1874, p. 226

Euglypha cristata Leidy 1879, p. 218-219, Pl. 37, Fig. 1-4

This taxon is elongate, ovoid with no obvious flattening, has a slightly constricted neck and is between $35-55 \mu \mathrm{m}$ in length. The aperture is small, terminal, circular and is bordered with plates with fine teeth. The test is composed of oval overlapping plates that are regularly arranged. A tuft of 2-3 very fine divergent spines protrudes from the aboral region plate junctions. Very rare in our samples so the range of morphological variability is probably under-estimated.

\section{Euglypha rotunda Wailes and Penard 1911 type (PI. 2, Fig. 1)}

Euglypha rotunda Wailes and Penard 1911, p. 65, Pl. 4, Fig. 19

Euglypha rotunda type Charman and others 2000b, p. 84, Fig. 21a$21 \mathrm{~b}$

The test is colorless and composed of approximately 120 oval, overlapping siliceous plates. Between $20-45 \mu \mathrm{m}$ in length and ovoid in broad lateral view. The aperture is $6-10 \mu \mathrm{m}$ in diameter, terminal, circular and surrounded by 8-14 plates. Distinguished from E.tuberculata type on the basis of size.

Euglypha strigosa (Ehrenberg 1872) Leidy 1878 (Pl. 2, Fig. 2) Diflugia strigosa Ehrenberg 1872 p. 257-258, Pl. 2, Fig. 31 Euglypha strigosa Leidy 1878, p. 172

Euglypha strigosa Charman and others 2000b, p. 84-85, Fig. 20a
Ovoid in broad lateral view, slightly compressed in narrow lateral view Slender spines scattered over the surface. The test is colorless and is composed of oval siliceous plates. The aperture is terminal, circular, $10-20 \mu \mathrm{m}$ in diameter and bordered by thickened plates. This taxon is generally $45-80 \times 20-40 \mu \mathrm{m}$ in broad lateral view.

Euglypha tuberculata Dujardin 1841 type (PI. 2, Fig. 5)

Euglypha tuberculata Dujardin 1841 type, p. 251-252

Euglypha tuberculata type Charman and others 2000b, p. 85, Fig. 21c

Similar to $E$ rotunda type but separated by size and proportionately larger plates. Length $45-100 \mu \mathrm{m}$, ovoid in broad lateral view. Aperture diameter is $15-25 \mu \mathrm{m}$, terminal, circular and bordered by plates.

\section{Heleopera petricola Leidy 1879}

Heleopera petricola Leidy 1879, p. 165-166, Pl. 26, Fig. 12-20 Heleopera petricola Charman and others 2000b, p. 88, Fig. 23a

The genus Heleopera is characterized by the asymmetric arrangement of xenosomes that are concentrated towards the aboral end of the test. The test of the test sometimes has plates, but these may be difficult to see in fossil or degraded form. Separation of species is based upon the shape of the test and nature of the aperture. Heleopera petricola is $75-85 \mu \mathrm{m}$ length $\times 50-60 \mu \mathrm{m}$ breadth. Test is ovoid in broad lateral view and flattened in narrow lateral view. The test is colorless, but variable and composed of siliceous plates with quartz particles in the aboral region. The aperture is terminal, $30-35 \mu \mathrm{m}$ diameter, with thickened margins. It has a slightly convex, elliptical opening bordered by organic cement. Rare in our samples and not illustrated here.

\section{Heleopera sylvatica Penard 1890}

Heleopera sylvatica Penard 1890, p. 168, Pl. 7, Fig. 79-94

Heleopera sylvatica Charman and others 2000b, p. 89, Fig. 23b

Heleopera sylvatica is smaller and narrower than $H$. petricola at 55$70 \mu \mathrm{m}$ in length and $25-30 \mu \mathrm{m}$ in breadth. The test is colorless with small quartz particles, the aperture is terminal and strongly convex, and curves smoothly round to sidewalls. Rare in our samples and not illustrated here.

\section{Hyalosphenia subflava Cash and Hopkinson 1909}

Hyalosphenia subflava Cash and Hopkinson 1909, p. 87-89, Pl. 31, Fig. 9-12

Hyalosphenia subflava Charman and others 2000b, p. 92, Fig. 24b

This taxon is normally $50-60 \mu \mathrm{m}$ in length and $35-40 \mu \mathrm{m}$ in breadth. The test is ovoid, broad in lateral view and elliptical in narrow lateral view. This outline may be distorted on occasion. The test is colorless or yellow, composed of smooth proteinaceous material and has a circular, terminal aperture which sometimes has pores around it. Extremely common in terrestrial peats but rare in our samples and not illustrated here.

Tracheleuglypha dentata Penard 1890 (PI. 2, Fig. 7)

Sphenoderia dentata Penard 1890, p. 185, Pl. 10, Fig. 41-50

Tracheleuglypha dentata Charman and others 2001, Fig. 8g-8h

This is one of the most abundant testate amoebae found in salt marshes and we have mentioned it in several previous papers (Charman and others, 1998; Gehrels and others, 2001). It is distinguished by its oval or circular plates and collar of cement which has a toothed margin. The structure of the test is sometimes degraded by partial decay.

Trigonopyxis arcula (Leidy 1879) Penard 1912 type (PI. 2, Fig. 8)

Difflugia arcula Leidy 1879, p. 116-117, Pl. 15, Fig. 34-37; Pl. 16, Fig. 30-31

Trigonopyxis arcula Penard 1912, p. 9-13, Pl. 1, Fig. 6

Trigonopyxis arcula type, Charman and others 2000b, p. 68-69, Fig. $13 \mathrm{c}-13 \mathrm{~d}$ Usually $110-130 \mu \mathrm{m}$ in diameter, the test is circular in broad lateral view and hemispherical in narrow lateral view. The test is dark brown and composed of mineral material held together by organic cement. The aperture is central and noncircular, most frequently appearing as a rough triangle, although it may also sometimes be a ragged circle or four-sided (Bobrov and others, 1999). The aperture may be invaginated, with a diameter of $21-42 \mu \mathrm{m}$. This test is not difficult to differentiate from Cyclopyxis arcelloides type as that taxon has a much larger, smooth, circular aperture and is a much deeper bowl shape in narrow lateral view. 
APPENDIX 2

Little Dipper Harbour, Chance Harbour, New Brunswick

\begin{tabular}{|c|c|c|c|c|c|c|c|c|c|c|c|c|c|c|c|c|c|}
\hline Sample code & NBO1 & NB02 & NBD3 & NBO4 & NB05 & NBD6 & NB07 & NB08 & NBO9 & NB10 & NB11 & NB12 & NB13 & NB14 & NB15 & NB16 & NB17 \\
\hline Distance along transect $(\mathrm{m})$ & 0.0 & 0.5 & 1.0 & 1.5 & 2.0 & 3.0 & 4.0 & 5.0 & 5.5 & 7.0 & 9.0 & 11.0 & 15.0 & 16.0 & 17.0 & 17.5 & 18.0 \\
\hline Height above NGVD-1929 (m) & 4.63 & 4.54 & 4.54 & 4.46 & 4.44 & 4.39 & 4.36 & 4.35 & 4.36 & 4.27 & 4.24 & 4.18 & 4.07 & 4.07 & 3.98 & 3.88 & 3.90 \\
\hline Arcella catinus type & 8 & 1 & 0 & 1 & 11 & 5 & 13 & 2 & 13 & 2 & 0 & 0 & 10 & 1 & 2 & 3 & 2 \\
\hline Centropyxis aculeata type & 1 & 0 & 0 & 0 & 0 & 0 & 0 & 0 & 0 & 1 & 0 & 2 & 0 & 1 & 3 & 6 & 0 \\
\hline Centropyxis cassis type & 18 & 15 & 8 & 7 & 31 & 19 & 62 & 10 & 9 & 89 & 45 & 132 & 128 & 145 & 90 & 4 & 0 \\
\hline Centropyxis platystoma type & 5 & 0 & 0 & 0 & 3 & 8 & 5 & 5 & 2 & 0 & 0 & 0 & 4 & 11 & 48 & 87 & 0 \\
\hline Cyclopyxis arcelloides type & 51 & 7 & 8 & 9 & 19 & 19 & 3 & 2 & 0 & 0 & 0 & 0 & 0 & 0 & 0 & 0 & 0 \\
\hline Trigonopyxis arcula type & 0 & 0 & 0 & 1 & 0 & 1 & 3 & 1 & 0 & 0 & 0 & 0 & 0 & 0 & 0 & 0 & 0 \\
\hline Diffugia pristis type & 0 & 0 & 0 & 0 & 0 & 0 & 0 & 1 & 0 & 0 & 2 & 3 & 3 & 0 & 7 & 49 & 0 \\
\hline Diffiugia pulex type & 0 & 1 & 0 & 0 & o & 0 & 0 & 0 & 0 & 0 & 0 & a & 1 & 0 & 0 & 0 & 0 \\
\hline Assulina muscorum & 1 & 5 & 3 & 3 & 22 & 18 & 15 & 2 & 9 & 1 & 0 & 0 & 0 & 0 & 0 & 0 & 0 \\
\hline Valkanovia elegans & 19 & 70 & 46 & 1 & 2 & 1 & 1 & o & 0 & 0 & 0 & 2 & 1 & 0 & 0 & 0 & 0 \\
\hline Assulina seminutum & 4 & 2 & 0 & 0 & 0 & 5 & 0 & 0 & 0 & 0 & 0 & 0 & 0 & 0 & 0 & 0 & 0 \\
\hline Euglypha rotunda type & 0 & 2 & 2 & 1 & 3 & 2 & 4 & 1 & 0 & 40 & 0 & 9 & 3 & 0 & 0 & 0 & 0 \\
\hline Euglypha tubercuiata type & 2 & 3 & 23 & 0 & 2 & 1 & 0 & 0 & 0 & 0 & 0 & 0 & 0 & 0 & 0 & 0 & 0 \\
\hline Heleoptera sy/vatica & a & 0 & 0 & 0 & 2 & 1 & 0 & 0 & 0 & 0 & 0 & 0 & 0 & o & 0 & 0 & 0 \\
\hline Hyalosphenia subflava & 0 & 0 & 0 & 2 & 4 & 0 & 0 & 5 & 0 & 0 & 0 & 0 & 0 & 1 & 0 & 0 & 0 \\
\hline Tracheleuglypha dentata & 15 & 36 & 44 & 6 & 49 & 21 & 41 & 9 & 4 & 17 & 8 & 2 & 0 & 0 & 0 & 0 & 0 \\
\hline Corythion dubium & 4 & 7 & 4 & 0 & 1 & 0 & 1 & 1 & 0 & 0 & 0 & 0 & 0 & 0 & 0 & 0 & 0 \\
\hline Trinema lineare & 15 & 0 & 3 & 0 & 0 & 0 & 0 & 0 & o & 0 & 0 & 0 & 0 & 0 & 0 & 0 & 0 \\
\hline Trinema complanatum & 10 & 0 & 9 & 1 & 1 & 0 & 2 & 1 & 0 & 0 & 0 & 0 & 0 & 0 & 0 & 0 & 0 \\
\hline Ttotal & 153 & 149 & 150 & 32 & 150 & 120 & 150 & 40 & 37 & 150 & 55 & 150 & 150 & 159 & 150 & 149 & 2 \\
\hline
\end{tabular}

Little River marsh, Wells, Maîne

\begin{tabular}{|c|c|c|c|c|c|c|c|c|c|c|c|c|c|c|c|c|c|}
\hline Sample code & ME01 & $\mathrm{MEO2}$ & ME03 & MEO4 & ME05 & ME06 & $M E 07$ & MEO 8 & ME09 & ME10 & ME11 & ME12 & ME13 & ME14 & ME15 & ME16 & ME17 \\
\hline Distance along transect $(\mathrm{m})$ & 0.0 & 4.1 & 5.4 & 6.3 & 7.4 & 8.2 & 8.7 & 9.6 & 10.3 & 11.7 & 20.3 & 25.3 & 29.6 & 34.4 & 44.3 & 49.0 & 49.8 \\
\hline Height above NGVD-1929 (m) & 2.54 & 2.48 & 2.40 & 2.35 & 2.27 & 2.20 & 2.15 & 2.09 & 2.00 & 1.91 & 1.82 & 1.79 & 1.75 & 1.72 & 1.63 & 1.56 & 1.49 \\
\hline Arcella catinus & 0 & 0 & 0 & 1 & 3 & 5 & 3 & 3 & 5 & 24 & 120 & 51 & 43 & 31 & 1 & 4 & 3 \\
\hline Centropyxis aculeata type & o & 0 & 0 & 0 & 4 & 5 & 0 & 3 & 12 & 81 & 0 & 0 & 0 & 0 & 1 & 1 & 0 \\
\hline Centropyxis cassis type & 10 & 7 & 26 & 11 & 16 & 21 & 23 & 35 & 69 & 29 & 6 & 0 & 4 & 0 & 0 & 0 & 28 \\
\hline Centropyxis platystoma type & 0 & 2 & 2 & 3 & 8 & 16 & 13 & 5 & 0 & 4 & 0 & 24 & 12 & 24 & 83 & 55 & 41 \\
\hline Cyclopyxis arcelloides type & 32 & 29 & 38 & 32 & 29 & 14 & 11 & 10 & 5 & 1 & 1 & 2 & 0 & 0 & 0 & 4 & 2 \\
\hline Trigonopyxis arcula type & 2 & 1 & 0 & 0 & 2 & 0 & 2 & 2 & 3 & 1 & 2 & 1 & 0 & 0 & 0 & 1 & 1 \\
\hline Diffugia kabylica type & 0 & 0 & 0 & 0 & 0 & 0 & 0 & 0 & 0 & 0 & 0 & 8 & 2 & 0 & 0 & 0 & 0 \\
\hline Difflugia pristis type & 0 & 0 & 1 & 0 & 4 & 2 & 12 & 1 & 4 & 0 & 14 & 62 & 62 & 64 & 57 & 83 & 75 \\
\hline Difflugia pulex type & 0 & 0 & 0 & 0 & 0 & 0 & 0 & 11 & 0 & 0 & 2 & 14 & 26 & 23 & 5 & 1 & 0 \\
\hline Assulina muscorum & 4 & 4 & 0 & 1 & 1 & 0 & 0 & a & 0 & 0 & 1 & 0 & 0 & 0 & 1 & 0 & 0 \\
\hline Valkanovia elegans & 42 & 50 & 30 & 37 & 4 & 4 & 2 & 30 & 2 & 0 & 0 & 0 & 1 & 0 & 0 & 0 & 0 \\
\hline Euglypha cristata & 0 & 0 & 0 & 2 & 0 & 0 & 0 & 0 & 0 & 0 & 0 & 0 & 0 & 0 & 0 & 0 & 0 \\
\hline Euglypha rotunda type & 0 & 4 & 2 & 1 & 2 & 0 & 0 & 10 & 45 & 4 & 0 & 0 & 0 & 8 & 0 & 1 & 0 \\
\hline Euglypha strigosa & 2 & 1 & 0 & 0 & 0 & 0 & 0 & 11 & 1 & 0 & 0 & 0 & 0 & 0 & 0 & 0 & 0 \\
\hline Euglypha tuberculata type & 2 & 2 & 0 & 0 & 0 & 0 & 0 & 3 & 1 & 0 & 0 & 0 & 0 & 0 & 0 & 0 & 0 \\
\hline Heieoptera petricola & 0 & 0 & 0 & 0 & 0 & 1 & 1 & 0 & 0 & 0 & 0 & 0 & 0 & 0 & 0 & 0 & 0 \\
\hline Heleoptera syivatica & 0 & 0 & 1 & 1 & 1 & 2 & 0 & 0 & 0 & 0 & 0 & 0 & 0 & 0 & 0 & 0 & 0 \\
\hline Tracheleuglypha dentata & 10 & 23 & 28 & 32 & 57 & 40 & 70 & 16 & 1 & 0 & 0 & 0 & 0 & 0 & 0 & 0 & 0 \\
\hline Conythion dubium & 14 & 8 & 11 & 7 & 3 & 0 & 5 & 1 & 1 & 1 & 0 & 0 & 0 & 0 & 0 & 0 & 0 \\
\hline Trinema lineare & 2 & 13 & 9 & 10 & 18 & 40 & 7 & 2 & a & 0 & 0 & 0 & 0 & 0 & 2 & 0 & 0 \\
\hline Trinema compianatum & 30 & 6 & 4 & 11 & 0 & 0 & 1 & 2 & 1 & 0 & 0 & 0 & 0 & 0 & 0 & 0 & 0 \\
\hline Cyphoderia ampulla & 0 & 0 & 0 & 0 & 0 & 0 & 0 & 2 & 0 & 0 & 0 & 2 & 2 & 0 & 2 & 12 & 3 \\
\hline Total & 150 & 150 & 162 & 149 & 152 & 150 & 150 & 147 & 150 & 145 & 146 & 164 & 152 & 150 & 152 & 162 & 153 \\
\hline
\end{tabular}


APPENDIX 2 Continued.

Leipsic River marsh, Delaware

\begin{tabular}{|l|r|r|r|r|r|r|r|r|r}
\hline Sample code & DL01 & DL02 & DL03 & DL04 & DLO5 & DL06 & DL07 & DL08 & DL09 \\
\hline Distance along transect (m) & 0 & 20 & 22 & 25 & 30 & 35 & 43 & 45 & 47 \\
\hline Height above NGVD-1929 (m) & 1.188 & 1.018 & 1.012 & 1.015 & 1.026 & 1.029 & 1.038 & 0.997 & 1.047 \\
\hline Arcella catinus type & 0 & 11 & 22 & 5 & 19 & 5 & 17 & 6 & 4 \\
\hline Centropyxis aculeata type & 0 & 3 & 9 & 5 & 15 & 1 & 1 & 2 & 0 \\
\hline Centropyxis cassis type & 11 & 3 & 11 & 0 & 0 & 0 & 0 & 0 & 0 \\
\hline Centropyxis platystoma type & 0 & 75 & 66 & 118 & 55 & 94 & 81 & 128 & 94 \\
\hline Cyclopyxis arcelloides type & 18 & 0 & 0 & 0 & 0 & 0 & 0 & 1 & 0 \\
\hline Trigonopyxis arcula type & 2 & 0 & 4 & 0 & 0 & 1 & 0 & 0 & 0 \\
\hline Diffugia pristis type & 0 & 16 & 18 & 12 & 5 & 28 & 10 & 10 & 7 \\
\hline Difflugia pulex type & 0 & 42 & 19 & 7 & 56 & 21 & 41 & 3 & 45 \\
\hline Valkanovia elegans & 6 & 0 & 0 & 0 & 0 & 0 & 0 & 0 & 0 \\
\hline Euglypha rotunda type & 29 & 0 & 0 & 3 & 0 & 0 & 0 & 0 & 0 \\
\hline Euglypha tubercuiata type & 2 & 0 & 0 & 0 & 0 & 0 & 0 & 0 & 0 \\
\hline Tracheleuglypha dentata & 16 & 0 & 0 & 0 & 0 & 0 & 0 & 0 & 0 \\
\hline Trinema lineare & 40 & 0 & 0 & 0 & 0 & 0 & 0 & 0 & 0 \\
\hline Trinema complanatum & 26 & 0 & 0 & 0 & 0 & 0 & 0 & 0 & 0 \\
\hline Total & 150 & 150 & 149 & 150 & 150 & 150 & 150 & 150 & 150 \\
\hline
\end{tabular}

